\title{
Key Characteristics of a Successful IS Manager: Empowerment, Leadership and personality
}

\author{
Louis P. White \\ University of Houston Clear Lake \\ 2700 Bay Area Blvd \\ Houston Texas 77058 \\ whitel@uhcl.edu \\ Constance M. Lafayette \\ Total Safety, US Inc \\ 11111 Wilcrest Green, Ste 300 \\ Houston Texas 77042 \\ Rachel Wang \\ College of Medicine at the \\ National Cheng Kung University, Taiwan
}

\begin{abstract}
This study examines the relationship between empowerment of IS managers and IS department performance. Data on perceived empowerment, leadership styles, and personality; department performance were collected from 148 managers of IS departments in Taiwan. Information on organizational culture and structure were investigated to assess the moderating effects of these factors on empowerment and performance.

Our findings show that highly empowered IS managers have higher performing IS departments. Findings also show that transformational leadership has a positive impact on performance. Data from the BFPI indicate that conscientiousness and agreeableness, as managerial traits, have a significant positive effect on performance. The same was not true for Extroversion, Neuroticism, and Openness which had no significant impact on performance.

The results are limited by our small sample and the inclusion of data from a single global region. Suggestions are offered for future research to overcome these limitations
\end{abstract}

Keywords: Information System Leadership, Empowerment, Key Success Factors 
Key Characteristics of a Successful IS Manager: Empowerment, Leadership and personality / White et al.

\section{Introduction}

With the increased importance of information systems, it is important that organizations manage their information systems department (ISD) effectively. In many companies, a senior manager oversees the strategic use of IT in the firm (Laudon \& Laudon, 2002). The increased reliance on IT calls for more study of how organizations are responding to environmental forces that influence the increasing role of IT in achieving business goals. There are many factors that may affect the performance of an ISD, one of which is whether the department manager is performing the job competently. A large body of literature has investigated the effectiveness of IS success at the systems level. A well-known model is the IS success model proposed by DeLone and McLean, which argues that IS quality determines system use and user satisfaction. However, few previous papers have examined the important role of IS managers in the delivery of IS services at the department level. It is well-accepted that a good manager with good leadership can make a significant difference for the organization. Therefore, it is important to examine whether different types of IS managers affects the performance of the ISD under their management.

There are different ways that a manager can be classified. In this study, we focus on three major characteristics of IS managers: empowerment, leadership style, and personality traits, and examine how they affect the performance of ISD. We also examine whether organizational culture and structure would have moderating effects on the effectiveness of IS manager. Research has shown that employee empowerment, leadership styles, and personality traits are key factors that affect productivity. The best companies accomplish this by empowered employees who take the initiative without prodding, serve the collective interests of the company without being micro-managed, and act like owners of the business (O'Toole \& Lawler, 2006). Transformational leaders and those manifesting internal locus of control characteristics are expected to perform better. We address a fundamental question is, "do empowered managers result in higher performing departments or units?" We have asserted that a relationship exists between empowered managers and productivity however, the empowerment process is influenced by organizational culture, structure, and leadership style and personality characteristics of the manager. Our intent was to assess the role of each factor in the relationship between empowerment of IT managers and IS department performance.

An empirical study involving data collection and statistical analyses to test hypotheses was performed. Our results show that manager empowerment, transformational leadership and personal traits do have significant effect on the performance of ISD. Organizational structure and culture, however, do not significant moderating effect on this relationship.

\section{Literature Review}

\section{Empowerment}

Empowerment is an increased intrinsic task motivation reflecting an individual's orientation to his or her work role. Conger and Kanungo (1988) viewed empowerment as a process of enhancing feelings of self-efficacy among organizational members through the identification of conditions that foster powerlessness. Thomas and Velthouse (1990) defined empowerment as a set of cognitions or states influenced by the work environment that helps create an active orientation to one's job. Generally, empowerment is seen from a psychological and social-structural perspective. Psychological empowerment refers to a set of psychological states that are necessary for individuals to feel a sense of control in relation to their work. The socialstructural perspective on empowerment is rooted in theories of social exchange and social power. The social-structural perspective is supported by the values and ideas of democracy where power can reside within individuals at all levels of a system (Prasad, 2001; Prasad \& Eylon, 2001). The essence of the social structural perspective of empowerment is the idea of sharing power among superiors 
Key Characteristics of a Successful IS Manager: Empowerment, Leadership and personality / White et al.

and subordinates with the goal of cascading relevant decision-making power to lower levels of the organizational hierarchy (Liden \& Arad, 1996).

Research has shown that employees who feel empowered are more motivated to perform effectively (Chen et al., 2007; Chen \& Klimoski, 2003; Liden et al., 2000; Empowerment is not only related to positive work attitudes, it has also been found to be related to positive work performance; managerial effectiveness (Spreitzer, 1995), employee effectiveness (Spreitzer et al., 1997), employee productivity (Koberg, et al., 1999), and newcomer role performance (Chen \& Klimoski, 2003). Spreitzer, DeJanasz, and Quinn (1999) found that supervisors, who reported high levels of empowerment, were seen by their subordinates as more innovative, upward influencing, and inspirational. Empowerment also is associated with more innovation at work (Spreitzer, 1995) and with more organizational citizenship behaviors (Wat \& Shaffer, 2005). More recently, Spreitzer (1997; 2006) distilled the interdisciplinary literature on empowerment, drawing on psychology sociology, social work, and education. In this study, we used Spreitzer's (1995) psychological empowerment model and constructs to examine the levels of psychological empowerment among IT managers in Taiwan.

While Bowen \& Lawler (1992) noted that five elements; information, knowledge, discretion, meaning, and rewards form the basis for empowerment; more recently Spreitzer (1995) found wide support for four dimensions of empowerment. They are: a) meaning, seen as the value of work goals or purposes as they are judged in relation to an individual's own personal ideas; (Thomas and Velthouse, 1990); b) competence or self-efficacy, defined as an individual's belief in his/her capability to perform activities with skill (Gist, 1987); c) self-determination, which reflects autonomy in the initiation and continuation of work behaviors and processes (Bell \& Staw, 1989; Spector, 1988); and d) impact, which is the degree to which an individual can influence strategic, administrative, or operating outcomes at work (Ashforth, 1989). Validity of the four dimen- sions of psychological empowerment has been established, and the structure of measure has been shown to be invariant across gender (Boudarias, Gaudreau, Laschinger, 2004).

Moving from research at the individual level to team level have also shown a relationship between empowerment and performance (Huselid, Becker, \& Beatty, 2005; Bernardin, 2010). Specific team factors that have been researched include team performance (Seibert, Silver, \& Randolph, 2004), (Kirkman \& Rosen, 1999), team process improvement (Spreitzer, Noble, Mishra, \& Cooke, 1999), customer satisfaction (Mathieu, Gilson \& Ruddy, 2006) and team effectiveness (Chen et al., 2007; Kirkman, Tesluk \& Rosen, 2004). Empowered team members are also more proactive, satisfied with their jobs, and committed to the team and the organization (Kirkman \& Rosen, 1999).We focused on the psychological empowerment of the manager and the extent to which empowerment influences the work group performance.

\section{Leadership}

The focus of our research was to test for the effects of empowerment on productivity; however, leadership behavior is an important part of the empowerment process. Leadership has been seen as the focus of group processes, a personality attribute, the art of inducing compliance, an exercise of influence, a particular kind of act, a form of persuasion, a power relation, an instrument in the attainment of goals, an effect of interaction, a differentiated role, and as the initiation of structure and many combinations of these definitions (Morris \& Seeman, 1950; Shartle, 1951a, 1951b, 1956; Carter, L. F. 1953; C. A. Gibb, 1954, 1969a; Bass, 1960; Stogdill, 1975; Schriesheim \& Kerr, 1977b). Researchers have investigated the influence of leadership style on performance (Eagly \&JohannesenSchmidt (2001). Not all styles of leadership are effective in management however (Bass, 1985). A transactional leader, for example attempts to maintain the status quo, whereas a transformational leader will take a proactive role in changing organizational culture to 
Key Characteristics of a Successful IS Manager: Empowerment, Leadership and personality / White et al.

meet new challenges. House, Barry \& Hjelle (1988) posited that transformational leadership is an emotional attachment to the leader resulting in emotional and motivational arousal of followers as an outcome of the leader's behavior.

Transformational leadership behaviors have been shown to have a positive relationship with performance (Lowe, Kroeck \& Sivasubramaniam, 1996). Transformational leaders exhibit charismatic behaviors, arouse inspirational motivation, provide intellectual stimulation, and treat followers with individualized consideration. These behaviors transform their followers by helping them to reach their full potential and generate the highest level of performance.

While research has shown that transformational leadership does influence performance, its role in the relationship between empowerment and subordinate performance has not been defined in postmodern organization behavior research. In this study, we explore the impact of transformational leadership on the relationship between a manager's psychological empowerment and the performance of the organizational unit they manage.

\section{Personality}

Individuals who express a transformational style of leadership also exhibit certain personality traits that affect the followership of others. As with leadership style, personality characteristics might also influence the relationship between empowerment and performance. Leaders display personality traits through patterns in their behavior. Personality characteristics are dispositional motivators utilized during goal attainment (Buss, 1991). Personality characteristics predispose humans to behave in certain ways, given particular stimulations, to accomplish certain goals (Buss, 1989; Costa \& McCrae, 1992). Although many articulations of personality characteristics exist, research has found that the Big Five factors provide a useful typology (Digman, 1990; Goldberg, 1992, 1993; McCrae \& Costa, 1987, 1989; McCrae \& John, 1992). These five factors were found repeatedly through factors analyses and con- firmatory factor analyses across, time, contexts, and cultures (Buss, 1991; Digman, 1990; Goldberg, 1992; 1993; McCrae \& Costa, 1987, 1989; McCrae \& John, 1992).

George, (1992) and Schneider, (1996) have shown personality traits to be reliable predictors of job performance and are widely used in selection decisions. More recently personality research has shown it to be an important factor involved in goal- focused leadership (Colbert \& Witt, 2009); commitment ( Aizen, Czasch, \& Flood, 2009); and more specific to this research, as it relates to job satisfaction in information technology (Acuna, Gomez, \& Juristo, 2009).

"Personality refers to the set of unseen characteristics and processes that underlie a relatively stable pattern of behavior in response to ideas, objects, or people in the environment" (Daft, 2007 pp.99). The Big Five is one of the most widely used inventories for measuring personality and is the most researched model of personality (John \& Srivastava, 1999; Costa \& McCrae 1999). The traits measured by the Big five are (1) Extroversion, (2) Agreeableness (likability), (3) Conscientiousness, (4) Neuroticism (or low Emotional Stability), (5) Openness to experience (or Intellect) (Digman, 1990; Barrick and Mount, 1993; Wiggins and Pincus, 1992; Zimmer, 2005) .Reviews and meta-analyses have shown a consistent taxonomy of the Big Five personality traits and specific performance criteria (George, 1992). These results suggest that there is potential value in personality as playing a role in the empowerment -performance relationship (Schneider, 1996; Borman et al., 1980; Lord et al., 1986; Day and Silverman, 1989; Barrick and Mount, 1991; Tett et al., 1991; (Driskell et al., 1987). Thus, we used the Big Five Personality Inventory to identify the personality traits of IT managers of high performing IT departments.

\section{Locus of Control}

Personality and thinking influence behavior, so in addition to personality, we used Locus of Control (LOC) (Rotter, 1966) as a possible influencing factor in the relationship between empowerment and performance. For a better 
Key Characteristics of a Successful IS Manager: Empowerment, Leadership and personality / White et al.

understanding of control in the empowerment process, control as defined by LOC, identifies people as internals and externals. Internals place primary responsibility for what happens on one's self, while those with an external orientation feel as though outside forces control them. Locus of control (LOC) has been widely studied since the mid-1960s as a personal antecedent of consequence to a leader/ manager's behavior. Durand and Nord (1976) showed that subordinates viewed supervisors with an Internal LOC as being considerate and initiating. Goodstadt and Hjelle (1973) found that supervisors with an external LOC were more likely to rely on formal authority while those with an internal LOC were more likely to rely on personal power when directing subordinates. Similarly, Mitchell, Symser, and Weed (1975) noted that supervisors with an external LOC were more likely to use coercion and legitimate authority, while supervisors with an internal LOC used rewards, respect, and expert power. These findings are consistent with those of several other studies showing that managers with an Internal LOC exhibited more task-centered effort and performed better than do those with an External LOC (Anderson, 1977). Moreover, managers with an Internal LOC have higher activity levels than do those with an External LOC (Brockhaus, 1975; Durand \& Shea, 1974). Johnson, Luthans, and Hennessey (1984) showed that the leader's LOC affected the amount of influence on their subordinates' productivity and satisfaction with them as leaders.

\section{Organization Culture}

In addition to leadership style, personality, and LOC as influencers of the empowerment - performance relationship, contextual factors can also influence performance. Organizational culture is an important mechanism for attracting, motivating, and retaining talented employees and has been noted as possibly the single best predictor of overall organizational excellence (Kahn, 1998; Collins and Porras, 1994; Collins, 1995). Deal and Kennedy (1999) using several primary measures of financial performance showed that organizations with strong cultures outper- form organizations with weak cultures. According to Schein (1992), the functions of culture are to help organization members adapt and survive in a changing environment and organize the relationships amongst themselves to perform effectively. Culture affects the way members of the organization make sense of the organization and the world. Daft (2007) opines that culture can help an organization be competitive and that leaders can influence cultural values toward high performance.

Varieties of frameworks have been proposed for conceptualizing organizational culture (Mitroff \& Kilmann, 1975, 1976; Mitroff, 1983; McDonald \& Gandz, 1992; Leavitt.1964). Denison and Mishra (1995) suggest a model consisting of four traits of organizational culture. These four traits form a framework with two orientations or contrasts; the contrast between internal integration and external adaption, and the contrast between change and stability. In their theoretical model of culture traits, Involvement and Consistency are characterized as "Internal Integration" while the traits of Adaptability and Mission are characterized as "External Orientation." These cultural traits are seen as adaptation processes of organizations and that specific culture traits may be useful predictors of performance and effectiveness. Involvement and consistency pertain to the dynamics of internal integration, while mission and adaptability address the dynamics of external adaptation. Involvement and adaptability describe traits related to an organization's capacity to change, while consistency and mission are more stable and predictable over time. More specifically, the traits of Involvement and adaptability are indicators of flexibility, openness and responsiveness, and are strong predictors of growth. In other words, culture is developed as an organization learns to cope with the dual problems of external adaptation and internal integration (Schein, 1990). Using the model proffered by Denison and Mishra, (1995) we projected that culture would act as a moderator of the relationship between empowerment and IT department performance. 
Key Characteristics of a Successful IS Manager: Empowerment, Leadership and personality / White et al.

\section{Organization Structure}

In addition to organizational culture as a contextual variable, we included structure. The structure of an organization consists of characteristics that determine the management processes used to orchestrate and control its decision-making activities. The traditional dimensions of organizational structure include variables such as hierarchical levels, span of control, complexity, formalization, and centralization. Pugh, Hickson, Hinings, and Turner (1968) suggest four dimensions of structure; James \& Jones, (1976) and; Champion, (1975) suggest seven and eight dimensions, respectively. Montanari (1978) proposed 16 possible dimensions of structure. Sciulli (1998), on the other hand, suggested five characteristics that determine organizational structure: (1) centralization, (2) formalization, (3) complexity, (4) size, and (5) integration. Dalton, Todor, Spendolini, Fielding, and Porter (1980) reviewed the research examining possible relationships between structure and performance. They arranged the literature reviewed according to a distinction between "structural" dimensions (organization/subunit size, span of control, flat/tall hierarchy, and administrative intensity) and "structuring" dimensions (specialization, formalization, and centralization). In concluding their review, Dalton et al. suggest that knowledge of the structure-performance relationships could be enhanced. These researchers have in common that structure is a means for organizations to align themselves to be in harmony with their environment.

Porter and Lawler, (1965); Kohn \& Schooler, (1973); Hall, (1977); Berger and Cummings,
(1979) have studied the relationships between properties of overall organizational structure and the psychological, attitudinal, and behavioral responses of individual employees. The varied approaches to the study of structure led Child (1974) to argue for closure by suggesting that some agreement has emerged in that the three main structural elements in organizations are complexity, decentralization, and formalization. In our study, we used the two most commonly used dimensions of organizational structure; they are formalization and centralization (Menom \& Varadarajan, 1992). We projected that there would be a significant moderating effect of organizational structure on the relationship between psychological empowerment of IT managers and the performance of their departments.

\section{Research Hypotheses and Methodology}

Based on the above literature, we developed four major hypotheses to be tested in the research as shown in Table 1.

\section{Research Instrument}

The questionnaire used in our study consisted of four sections: (1) IS manager characteristics (Empowerment, leadership style, and Personality traits), (2) IS department performance, (3) internal environment (organizational culture and organizational Structure), and (4) demographics of respondents. The scale for each question was a standard Likert scale of 1-7 with 1 as "strongly disagree" and 7 as "strongly agree."

\begin{tabular}{|c|c|}
\hline $\mathrm{H} 1$ & Empowerment of IS Manager has positive influence on ISD performance. \\
\hline $\mathrm{H} 2$ & Transformational leadership of IS manager has positive impact in ISD performance. \\
\hline H 3-1 & Different Big Five personality of IS manager would affect ISD performance. \\
\hline H 3-2 & $\begin{array}{l}\text { IS managers classified as Internal LOC will have significantly higher departmental per- } \\
\text { formance than those IS managers classified as External LOC. }\end{array}$ \\
\hline $\mathrm{H} 4-1$ & $\begin{array}{l}\text { There is significant moderating effect of organizational culture on IS manager char- } \\
\text { acteristics and ISD performance }\end{array}$ \\
\hline $\mathrm{H} 4-2$ & $\begin{array}{l}\text { There is significant moderating effect of organizational Structure on IS manager } \\
\text { characteristics and ISD performance. }\end{array}$ \\
\hline
\end{tabular}


Key Characteristics of a Successful IS Manager: Empowerment, Leadership and personality / White et al.

The 90-item survey questionnaire was mailed to IS managers of companies based in Taiwan. A pilot study $(\mathrm{N}=30)$, served as the basis for correcting, refining, and enhancing the experimental scales. Some items were eliminated if they represented the same aspects with only slightly different wording or modified if the semantics were ambiguous. In addition, our questionnaire also asked participants for information about (1) gender, (2) age, (3) education, (4) industry field, (5) firm age, (6) turnover in the last year, (7) number of employees in the firm, (8) number of employees in the IT department, (9) number of employees under your supervisor, (10) income/year.

\section{Participants}

We sent 1,200 questionnaires to the sample firms' IS managers and 157 questionnaires were returned; nine of which were unusable leaving 148 valid questionnaires, which results in an effective response rate of $12.33 \%$. To test our hypotheses, data from IT departments were gathered on the following constructs: psychological empowerment, leadership style, and personality measured by the Big Five, Locus of Control, organizational culture and structure (contextual factors). Twelve items were used to measure four dimensions of empowerment, three items for meaning, three items for competence, 3 items for self-determination and three items for impact (Spreitzer 1995).

Table 2 - Results of reliability tests on empowerment

\begin{tabular}{|c|c|c|c|c|c|c|c|}
\hline Factor & Mean & SD & $\begin{array}{l}\text { Eigen } \\
\text { value }\end{array}$ & $\begin{array}{c}\text { Explained } \\
\text { Variance } \\
(\%) \\
\text { Explained }\end{array}$ & $\begin{array}{l}\text { Fac } \\
\text { tor } \\
\text { Lo } \\
\text { adi } \\
\text { ng }\end{array}$ & $\begin{array}{c}\text { Cronbach's } \\
\text { A }\end{array}$ & $\begin{array}{l}\text { Item-to-total } \\
\text { Correlation }\end{array}$ \\
\hline Empowerment & & & & & & .922 & \\
\hline Self-determination & & & 2.633 & 21.943 & & .900 & \\
\hline $\begin{array}{l}\text { I have significant autonomy in } \\
\text { determining how I do my job. }\end{array}$ & 5.74 & 0.94 & & & .683 & & 0.84 \\
\hline $\begin{array}{l}\text { I can decide on my own how } \\
\text { to go about doing my work. }\end{array}$ & 5.74 & 0.91 & & & .811 & & 0.80 \\
\hline $\begin{array}{l}\text { I have considerable opportuni- } \\
\text { ty for independence and free- } \\
\text { dom in how I do my job. }\end{array}$ & 5.67 & 1.03 & & & .875 & & 0.72 \\
\hline Meaning & & & 2.626 & 43.830 & & .883 & \\
\hline $\begin{array}{l}\text { The work I do is very im- } \\
\text { portant to me. }\end{array}$ & 5.91 & 0.93 & & & .781 & & 0.69 \\
\hline $\begin{array}{l}\text { My job activities are personal- } \\
\text { ly meaningful to me. }\end{array}$ & 5.80 & 0.93 & & & .858 & & 0.75 \\
\hline $\begin{array}{l}\text { The work I do is meaningful to } \\
\text { me. }\end{array}$ & 5.81 & 0.91 & & & .782 & & 0.79 \\
\hline Competence & & & 2.308 & 63.062 & & .850 & \\
\hline $\begin{array}{l}\text { I am confident about my ability } \\
\text { to do my job. }\end{array}$ & 6.02 & 0.84 & & & .747 & & 0.74 \\
\hline $\begin{array}{l}\text { I am self-assured about my } \\
\text { capabilities to perform my } \\
\text { work activities }\end{array}$ & 5.96 & 0.82 & & & .857 & & 0.70 \\
\hline $\begin{array}{l}\text { I have mastered the skills } \\
\text { necessary for my job. }\end{array}$ & 5.77 & 0.89 & & & .639 & & 0.77 \\
\hline Impact & & & 2.130 & 80.813 & & .815 & \\
\hline $\begin{array}{l}\text { My impact on what happens in } \\
\text { my department is large. }\end{array}$ & 5.26 & 1.21 & & & .874 & & 0.57 \\
\hline $\begin{array}{l}\text { I have a great deal of control } \\
\text { over what happens in my de- } \\
\text { partment. }\end{array}$ & 5.46 & 1.05 & & & .727 & & 0.76 \\
\hline $\begin{array}{l}\text { I have significant influence } \\
\text { over what happens in my de- } \\
\text { partment in how I do my job. }\end{array}$ & 5.55 & 0.99 & & & .698 & & 0.77 \\
\hline
\end{tabular}


Key Characteristics of a Successful IS Manager: Empowerment, Leadership and personality / White et al.

Of the 148 respondents, 123 were men, 25 were women ranging in age from 21 to $59 ; 82$ had a four-year degree, 58 had a Master's degree, and the remaining 17 were high school graduates. Forty percent of the participating sample firms were Information Service/software and Electronic Retail manufacturing; twenty percent were Steel/Metal/electric machinery, with twenty percent from other industries. Sixty-one percent of participating firms employ more than 200 people. Roughly $57.7 \%$ of the sampled companies employ fewer than 10 people in the IS department and $71.8 \%$ of the IS managers of sampled companies supervise fewer than 10 employees.

\section{Data Analysis and Findings}

Factor analysis and item-to-total correlations were used to test for the internal consistency of each construct. Cronbach's a was used to measure squared correlation between observed scores and true scores. T-test was utilized to analyze the data between two populations. Multiple regression analysis was used to examine the relationship between the empowerment of IS manager and ISD performance. Characteristics of IS managers (Empowerment, leadership style and personality traits) were independent variables while IS department performance was the dependent variable.

A single factor analysis on the collected data shows that there is no common method bias. The results for internal consistency for the factors of empowerment are shown in Table 2. It is also shown that all variables within each factor have coefficients of item-to-total correlation greater than 0.5 , this represents an acceptable internal consistency within each factor. In addition, Cronbach's a for each factor further confirms the reliability of the variables.

Fifteen items were used to measure the ISD performance. Factor analysis was employed to identify the factors in the construct. All items loaded on factors that the original theory proposed, five items were eliminated; the remaining four factors explained $67.56 \%$ of the variance (Table 3 ). The construct's factor analysis and reliability tests met all required standards, factors with an item-to-total correlation greater than 0.5 ; with Cronbach's $\alpha$ values greater than 0.6 , there is confirmation that the constructs comprising ISD performance are reliable.

$\mathrm{H} 1$ : IS mangers reporting high levels of empowerment will have significantly higher ISD performance than IS managers reporting low levels of empowerment will.

Data from the Spreitzer's (1995) Psychological Empowerment model and ISD performance were compared to investigate the relationship between the level of empowerment of IS managers and ISD performance. Table 4 shows the r-values between Empowerment and ISD performance range from 0.754 to 0.632 , indicating a weak but consistent relationship. Our results indicate that managers with comparatively higher levels of empowerment tended to have the higher department performance. Therefore, the first hypothesis was supported.

$\mathrm{H} 2$ : IS managers who perceive themselves as transformational leaders will have significantly higher ISD performance than IS managers who do not perceive themselves as transformational leaders.

To test the second hypothesis, we used the leadership Style questionnaire and the ISD performance questionnaire. A factor analysis with varimax rotation permitted the elimination of three items; the remaining items had item-to-total correlations greater than 0.5 , this represents high consistency within each factor. Cronbach's $\alpha$ values for each factor are greater than 0.6 to confirm their reliability. Table 5 presents the results of the Pearson correlation analysis between leadership style and ISD performance.

The correlations between leadership style and ISD performance range from 0.4 to 0.6 with an overall $r$-value of 0.595 . We conclude therefore, that IS managers with a transformational leadership style can influence departmental performance in a positive direction. The second hypothesis is supported. 


\begin{tabular}{|c|c|c|c|c|c|c|c|}
\hline Factor & Mean & SD & $\begin{array}{l}\text { Eigen } \\
\text { Value }\end{array}$ & $\begin{array}{c}\text { Ex- } \\
\text { plained } \\
\text { Variance }\end{array}$ & $\begin{array}{l}\text { Factor } \\
\text { Loading }\end{array}$ & $\begin{array}{c}\text { Cronbach's } \\
\text { A }\end{array}$ & $\begin{array}{l}\text { Item-to-total } \\
\text { Correlation }\end{array}$ \\
\hline $\begin{array}{l}\text { IT department Perfor- } \\
\text { mance }\end{array}$ & & & & & & .933 & \\
\hline User Orientation & & & 2.435 & 24.355 & & .867 & \\
\hline $\begin{array}{l}\text { Customer (end-user) is } \\
\text { satisfied with IT services. }\end{array}$ & 5.24 & 1.01 & & & .643 & & 0.73 \\
\hline $\begin{array}{l}\text { The expected amount } \\
\text { (scope) of work that was } \\
\text { required by end-users was } \\
\text { completed on time. }\end{array}$ & 5.39 & 0.92 & & & .703 & & 0.73 \\
\hline $\begin{array}{l}\text { Allowed to improve pro- } \\
\text { cess and other require- } \\
\text { ments proposed by users. }\end{array}$ & 5.36 & 0.99 & & & .706 & & 0.76 \\
\hline $\begin{array}{l}\text { Completed work/service } \\
\text { was of a high quality. }\end{array}$ & 5.46 & 0.91 & & & .703 & & 0.79 \\
\hline Business Value & & & 1.693 & 41.288 & & .844 & \\
\hline The cost controls are met. & 5.32 & 1.00 & & & 609 & & 0.77 \\
\hline The budget is adhered to. & 5.39 & 0.98 & & & .921 & & 0.80 \\
\hline Internal Process & & & 1.344 & 54.733 & & .820 & \\
\hline $\begin{array}{l}\text { The average time required } \\
\text { to address an end-user } \\
\text { problem is short. }\end{array}$ & 5.60 & 0.86 & & & .503 & & 0.74 \\
\hline $\begin{array}{l}\text { The number of end-user } \\
\text { queries handled is low. }\end{array}$ & 5.61 & 1.02 & & & .812 & & 0.75 \\
\hline Future Readiness & & & 1.283 & 67.560 & & .660 & \\
\hline $\begin{array}{l}\text { Continuously update } \\
\text { /renew IT system for end- } \\
\text { user. }\end{array}$ & 5.35 & 0.99 & & & .696 & & 0.69 \\
\hline $\begin{array}{l}\text { Continuously upgrade IS } \\
\text { skills through training and } \\
\text { development. }\end{array}$ & 5.19 & 1.10 & & & .576 & & 0.49 \\
\hline
\end{tabular}

\section{Table 4 - Correlation coefficient (r-value) between empowerment and IT department per-} formance

\begin{tabular}{|l|c|c|c|c|c|}
\hline $\begin{array}{c}\text { Independent/Dependent } \\
\text { variable Construct }\end{array}$ & $\begin{array}{c}\text { Business } \\
\text { Value }\end{array}$ & $\begin{array}{c}\text { User } \\
\text { Orientation }\end{array}$ & $\begin{array}{c}\text { Internal } \\
\text { Process }\end{array}$ & $\begin{array}{c}\text { Future } \\
\text { Readiness }\end{array}$ & $\begin{array}{c}\text { IS } \\
\text { department } \\
\text { Performance }\end{array}$ \\
\hline Meaning & $.385^{* *}$ & $.425^{* *}$ & $.483^{* *}$ & $.412^{* *}$ & $.475^{* *}$ \\
\hline Competence & $.383^{* *}$ & $.434^{* *}$ & $.571^{* *}$ & $.373^{* *}$ & $.491^{* *}$ \\
\hline Self-Determination & $.550^{* *}$ & $.491^{* *}$ & $.557^{* *}$ & $.493^{* *}$ & $.597^{* *}$ \\
\hline Impact & $.470^{* *}$ & $.405^{* *}$ & $.510^{* *}$ & $.479^{* *}$ & $.542^{* *}$ \\
\hline Empowerment & $.541^{* *}$ & $.527^{* *}$ & $.635^{* *}$ & $.530^{* *}$ & $.632^{* *}$ \\
\hline
\end{tabular}

Note: ${ }^{* *}$ Correlation is significant at 0.001 levels or below, ${ }^{* *}$ Correlation is significant at 0.01 levels or below, ${ }^{*}$ Correlation is significant at 0.05 levels or below (2-tailed). 
Key Characteristics of a Successful IS Manager: Empowerment, Leadership and personality / White et al.

Table 5 - Correlation coefficient (r-value) between transformational leadership style and ISD performance

\begin{tabular}{|l|c|c|c|c|c|}
\hline $\begin{array}{c}\text { Independnt/Dependent } \\
\text { variable Construct }\end{array}$ & $\begin{array}{c}\text { Business } \\
\text { Value }\end{array}$ & $\begin{array}{c}\text { User } \\
\text { Orientation }\end{array}$ & $\begin{array}{c}\text { Internal } \\
\text { Process }\end{array}$ & $\begin{array}{c}\text { Future } \\
\text { Readiness }\end{array}$ & $\begin{array}{c}\text { IS department } \\
\text { Performance }\end{array}$ \\
\hline $\begin{array}{l}\text { Charisma/ } \\
\text { Inspiration }\end{array}$ & $.436^{* *}$ & $.517^{* *}$ & $.607^{* *}$ & $.460^{* *}$ & $.569^{* *}$ \\
\hline Individual Consideration & $.430^{* *}$ & $.502^{* *}$ & $.623^{* *}$ & $.523^{* *}$ & $.585^{* *}$ \\
\hline Intellectual Stimulation & $.341^{* *}$ & $.409^{* *}$ & $.515^{* *}$ & $.463^{* *}$ & $.481^{* *}$ \\
\hline Leadership Style & $.432^{* *}$ & $.521^{* *}$ & $.633^{* *}$ & $.533^{* *}$ & $.595^{* *}$ \\
\hline
\end{tabular}

Note: ${ }^{* * *}$ Correlation is significant at 0.001 levels or below, ${ }^{* *}$ Correlation is significant at 0.01 levels or below, ${ }^{*}$ Correlation is significant at 0.05 levels or below (2-tailed).

\begin{tabular}{|c|c|c|c|c|c|}
\hline $\begin{array}{c}\text { Independent/Dependent } \\
\text { variable Construct }\end{array}$ & $\begin{array}{l}\text { Business } \\
\text { Value }\end{array}$ & $\begin{array}{l}\text { User } \\
\text { Orientation }\end{array}$ & $\begin{array}{l}\text { Internal } \\
\text { Process }\end{array}$ & $\begin{array}{l}\text { Future } \\
\text { Readiness }\end{array}$ & $\begin{array}{l}\text { IS department } \\
\text { Performance }\end{array}$ \\
\hline Extroversion & $.303^{\star *}$ & $.318^{* *}$ & $.307^{* *}$ & $.309^{\star *}$ & $.354^{* *}$ \\
\hline Agreeableness & $.455^{\star *}$ & $.400^{* *}$ & $.386^{* *}$ & $.489^{* *}$ & $.490^{* *}$ \\
\hline Conscientiousness & $.436^{* *}$ & $.430^{\star *}$ & $.513^{* *}$ & $.429^{\star *}$ & $.508^{* *}$ \\
\hline Neuroticism & -.116 & $-.188^{*}$ & $-.208^{*}$ & -.142 & $-.186^{*}$ \\
\hline Openness To Experience & $.201^{*}$ & $.184^{*}$ & $.236^{* *}$ & $.275^{\star *}$ & $.256^{* *}$ \\
\hline Big Five & $.382^{* *}$ & $.328^{* *}$ & $.354^{* *}$ & $.402^{\star *}$ & $.414^{* *}$ \\
\hline
\end{tabular}

Note: ${ }^{* * *}$ Correlation is significant at 0.001 levels or below, ${ }^{* *}$ Correlation is significant at 0.01 levels or below, ${ }^{*}$ Correlation is significant at 0.05 levels or below (2-tailed).

\section{H 3-1: IS managers who score high in open-} ness, agreeability, consciousness, and extroversion on the BFI will have significantly higher ISD performance than IS managers who score low.

Each of the five factors assessed by the Big Five consists of three items. Reliability of the five items was acceptable with item-to-total correlation values between 0.3 and 0.5 . Cronbach's $\alpha$ for this construct exceeds 0.6 , indicating that the degree of internal consistency is acceptable for the five dimensions. The five factors explained $74.335 \%$ of the variance. Table 6 presents the results of the Pearson correlation analysis between the personality of IS managers and ISD performance.

The results in Table 6 indicate that Conscientiousness and Agreeableness show a stronger relationship to ISD performance than do the other factors. Values of 0.4 to 0.6 indicate that Conscientiousness and Agreeableness are moderately associated with ISD performance. Neuroticism and Openness to Experience are weakly associated with ISD performance. Overall, the correlation between the Big Five personality factors of IS manager and ISD performance is .414. We are safe in concluding that the personality of IS managers does influence departmental performance and therefore, accept the third hypothesis.

H 3-2: IS managers reporting Internal LOC will have significantly higher departmental performance than IS managers reporting External LOC will.

Locus of Control (LOC) scores were separated into two groups-- internal LOC and external LOC. Sixty-five respondents were scored as Internals while 83 respondents were classified as Externals. Cronbach's $\alpha$ of the measurement exceeded .6 to confirm the reliability of the LOC construct. Table 7 shows that the mean scores for Internals are higher than the mean of Externals for IT department performance measure. At a 0.001 level of significance ( $\mathrm{t}$-value $=4.370$ ), the mean of Internal LOC (22.6974) is significantly higher than External LOC (20.7622) indicating that an Internal LOC indicating a distinct separation of Internals and Externals. Comparison of LOC scores to department performance however, yielded in correlation coefficients 
Key Characteristics of a Successful IS Manager: Empowerment, Leadership and personality / White et al.

with r-values less than 0.4 indicate that for our sample LOC is not a powerful predictor of performance. We then reject our fourth hypothesis.

H4: Organizational culture and structure will have a significant moderating effect on the empowerment of IS managers and IS department performance.

Organizational culture was measured by eight variables, each having two dimensions. Adaptability and Mission define an "External Orientation" while Involvement and Consistency define an "Internal Integration." (Denison and Mishra, 1995) Results of factor analysis with the four factors explain $63.321 \%$ of the variance. The item-to-total correlation for each variable is higher than 0.5 , and Cronbach's $\alpha$ for this construct exceeds 0.6 -external orientation (.757) and internal integration (.755). This suggests a high degree of internal consistency for each dimension.

The fourth hypothesis acclaims that organizational culture and structure have a moderating effect on the relationship between Empowerment of IS managers and IS department performance. Tables 8 and 9 display the moderating effects of organizational culture and structure using multiple regression analysis.

\begin{tabular}{|c|c|c|c|c|}
\hline & LOC & Frequency & Mean & t-value \\
\hline \multirow{2}{*}{ Business Value } & Internal LOC & 65 & 5.5897 & \multirow{2}{*}{$3.444^{* *}$} \\
\hline & External LOC & 83 & 5.1044 & \\
\hline \multirow{2}{*}{ User Orientation } & Internal LOC & 65 & 5.5615 & \multirow{2}{*}{$2.681^{* *}$} \\
\hline & External LOC & 83 & 5.2078 & \\
\hline \multirow{2}{*}{ Internal Process } & Internal LOC & 65 & 5.8615 & \multirow{2}{*}{$4.683^{* * *}$} \\
\hline & External LOC & 83 & 5.3072 & \\
\hline \multirow{2}{*}{ Future Readiness } & Internal LOC & 65 & 5.6846 & \multirow{2}{*}{$4.813^{* * *}$} \\
\hline & External LOC & 82 & 5.1067 & \\
\hline \multirow{2}{*}{$\begin{array}{c}\text { Overall } \\
\text { Performance }\end{array}$} & Internal LOC & 65 & 22.6974 & \multirow{2}{*}{$4.370^{* * *}$} \\
\hline & External LOC & 82 & 20.7622 & \\
\hline
\end{tabular}

Note: ${ }^{* * *}$ Correlation is significant at 0.001 levels or below, ${ }^{* *}$ Correlation is significant at 0.01 levels or below, ${ }^{*}$ Correlation is significant at 0.05 levels or below (2-tailed).

\section{Table 8 - Influences of External Orientation Culture on empowerment and ISD per-} formance

\begin{tabular}{|c|c|c|c|c|c|c|c|c|c|}
\hline & \multicolumn{3}{|c|}{$\begin{array}{l}\text { Model 1: } \\
\text { without moderator }\end{array}$} & \multicolumn{3}{|c|}{$\begin{array}{c}\text { Model 2: } \\
\text { With External } \\
\text { Orientation }\end{array}$} & \multicolumn{3}{|c|}{$\begin{array}{c}\text { Model 3: } \\
\text { With External } \\
\text { Orientation } \\
\text { And Empowerment*EO }\end{array}$} \\
\hline & B & beta & $\mathbf{T}$ & B & Beta & $\mathbf{T}$ & B & beta & $\mathbf{T}$ \\
\hline (Constant) & 1.266 & & $4.667^{* * *}$ & .766 & & $2.794^{\star *}$ & -.486 & & -.321 \\
\hline Empowerment & .539 & .595 & $8.917^{* * *}$ & .438 & .477 & $7.219^{* * *}$ & .717 & .781 & 2.127 \\
\hline $\begin{array}{l}\text { External } \\
\text { Orientation }\end{array}$ & & & & .261 & .337 & $5.099 * * *$ & 617 & .796 & 1.449 \\
\hline Empowerment ${ }^{*}$ EO & & & & & & & -.079 & -.631 & -.841 \\
\hline $\mathbf{R}^{2}$ & \multicolumn{3}{|l|}{.354} & \multicolumn{3}{|l|}{448} & \multicolumn{3}{|l|}{451} \\
\hline Adj-R ${ }^{2}$ & \multicolumn{3}{|l|}{.350} & \multicolumn{3}{|l|}{.440} & \multicolumn{3}{|l|}{.439} \\
\hline F value & \multicolumn{3}{|c|}{$79.505^{\star * *}$} & \multicolumn{3}{|c|}{$57.640^{* * *}$} & \multicolumn{3}{|c|}{$38.583^{* * *}$} \\
\hline
\end{tabular}

Note: P-value ${ }^{* * *}$ represents significant level at 0.001 or below, P-value ${ }^{* *}$ represents significant level at 0.01 or below, $\mathrm{P}$-value* represents significant level at 0.05 or below. 


\begin{tabular}{|c|c|c|c|c|c|c|c|c|c|}
\hline & \multicolumn{3}{|c|}{$\begin{array}{c}\text { Model 1: } \\
\text { without moderator }\end{array}$} & \multicolumn{3}{|c|}{$\begin{array}{c}\text { Model 2: } \\
\text { With Internal } \\
\text { Integration(II) } \\
\end{array}$} & \multicolumn{3}{|c|}{$\begin{array}{c}\text { Model 3: } \\
\text { With Internal Integration } \\
\text { And Empowerment*II }\end{array}$} \\
\hline & B & Beta & $\mathbf{T}$ & B & Beta & $\mathbf{T}$ & B & beta & $\mathbf{T}$ \\
\hline (Constant) & 1.266 & & $4.667^{* \star *}$ & 1.033 & & $3.998^{* * *}$ & .443 & & .330 \\
\hline Empowerment & .539 & .595 & $8.917^{* * \star}$ & .402 & .437 & $6.418^{* * \star}$ & .532 & .579 & 1.784 \\
\hline Internal Integration & & & & .257 & .363 & $5.334^{* * *}$ & .443 & \begin{tabular}{|l|}
.628 \\
\end{tabular} & 1.055 \\
\hline Empowerment* II & & & & & & & -.041 & -.349 & -.447 \\
\hline $\mathrm{R}^{2}$ & \multicolumn{3}{|l|}{.354} & \multicolumn{3}{|l|}{.456} & \multicolumn{3}{|l|}{.457} \\
\hline Adj- $R^{2}$ & \multicolumn{3}{|l|}{.350} & \multicolumn{3}{|l|}{.448} & \multicolumn{3}{|l|}{.445} \\
\hline$F$ value & \multicolumn{3}{|c|}{$79.505^{* * *}$} & \multicolumn{3}{|c|}{$59.513^{* \star \star}$} & \multicolumn{3}{|c|}{$39.518^{* \star \star}$} \\
\hline
\end{tabular}

Note: P-value ** represents significant level at 0.001 or below, P-value ${ }^{* *}$ represents significant level at 0.01 or below, $\mathrm{P}$-value* represents significant level at 0.05 or below.

Table 8 shows the results of three models that include the external orientation culture: the multiple regressions without the external orientation variable in Model 1, with external orientation but no moderator in Model 2, and with the moderator of external orientation in Model 3. There was no significant difference in $R^{2}$ between Models 2 and 3 and the interaction term is not significant in Model 3 . Therefore, the moderating effect of external orientation is not significant. Model 2 shows that the value of $R^{2}$ increased from .354 in Model 1 to .448 and the coefficient of external orientation is positive. This indicates that the addition of an external orientation culture explains more influence on ISD performance. The external orientation culture has a significant positive effect on ISD performance.

Similar results hold for the moderator of internal integration culture. Table 9 shows that the $\mathrm{R}^{2}$ value increased from .354 (Model 1) to .456 (Model 2) when the culture variable is added. The moderating affect of internal integration culture on the relationship between empowerment of IS managers and ISD performance is insignificant. In sum, there is no significant moderating effect of organizational culture on the empowerment of IS managers and ISD performance. Therefore, hypothesis 4-1 is rejected.
Nine variables were used to differentiate the organizational structure into formalization and centralization. As in the previous section, factor analysis identified the dimensions of the construct. Two items were eliminated and the remaining factors explained $71.558 \%$ of the variance. The item-to-total correlation for variables is higher than 0.5 for the constructs of formalization and centralization. Cronbach's a exceeds 0.6 , indicating that the construct of organizational structure is reliable.

To test for the moderating effect of organizational structure on the relationship between empowerment of IS manager and ISD performance, we used three multiple regression models. Tables 10 and 11, show that formalization and centralization did not have a significant moderating effect on the relationship between empowerment and performance. Models 2 and 3 have nearly equal $R^{2}$ values, and both are higher than that of Model 1 . The interaction term is not significant. We can conclude, therefore, that formalization and centralization do not play a moderator role in the relationship between the empowerment of the IS manager and ISD performance. We, therefore reject hypothesis $4-2$. Since the direct effect of formalization is positive, we can see that organizational formalization helps improve the performance of IS department. 
Table 10 - Influences of structure on the empowerment of IS managers and on ISD performance

\begin{tabular}{|c|c|c|c|c|c|c|c|c|c|}
\hline & \multicolumn{3}{|c|}{$\begin{array}{c}\text { Model 1: } \\
\text { without moderator }\end{array}$} & \multicolumn{3}{|c|}{$\begin{array}{c}\text { Model 2: } \\
\text { With Formalization } \\
\text { (Formal.) }\end{array}$} & \multicolumn{3}{|c|}{$\begin{array}{c}\text { Model 3: } \\
\text { With Formalization } \\
\text { And Interaction. }\end{array}$} \\
\hline & B & Beta & $\mathbf{T}$ & B & Beta & $\mathbf{T}$ & B & beta & $\mathbf{T}$ \\
\hline (Constant) & 1.266 & & $4.667^{* \star *}$ & .996 & & $3.569^{* * *}$ & -.183 & & -.151 \\
\hline Empowerment & .539 & .595 & $8.917^{* * *}$ & .461 & .505 & $7.400^{* * *}$ & .720 & .788 & $2.706^{\star \star}$ \\
\hline Formalization & & & & .128 & .254 & $3.719^{* * *}$ & .388 & .765 & 1.484 \\
\hline $\begin{array}{l}\text { Empowerment* } \\
\text { Formal. }\end{array}$ & & & & & & & -.056 & -.659 & -1.001 \\
\hline $\mathrm{R}^{2}$ & \multicolumn{3}{|l|}{.354} & \multicolumn{3}{|l|}{397} & \multicolumn{3}{|l|}{.401} \\
\hline Adj-R ${ }^{2}$ & \multicolumn{3}{|l|}{.350} & \multicolumn{3}{|l|}{.388} & \multicolumn{3}{|l|}{.388} \\
\hline F value & \multicolumn{3}{|c|}{$79.505^{* * *}$} & \multicolumn{3}{|c|}{$47.048^{* * *}$} & \multicolumn{3}{|c|}{$31.699^{* * *}$} \\
\hline
\end{tabular}

Note: P-value ${ }^{* *}$ represents significant level at 0.001 or below, P-value ${ }^{* *}$ represents significant level at 0.01 or below, $\mathrm{P}$-value* represents significant level at 0.05 or below.

Table 11 - Influences of structure on empowerment of IT mangers and on IT department performance

\begin{tabular}{|c|c|c|c|c|c|c|c|c|c|}
\hline & \multicolumn{3}{|c|}{$\begin{array}{l}\text { Model 1: } \\
\text { without moderator }\end{array}$} & \multicolumn{3}{|c|}{$\begin{array}{l}\text { Model 2: } \\
\text { With Centralization } \\
\text { (Central) } \\
\end{array}$} & \multicolumn{3}{|c|}{$\begin{array}{c}\text { Model 3: } \\
\text { With Centralization } \\
\text { And Interaction. }\end{array}$} \\
\hline & B & Beta & $t$ & B & beta & $\mathrm{T}$ & B & beta & $t$ \\
\hline (Constant) & 1.266 & & $4.667^{* \star \star}$ & 1.449 & & $5.007^{\star \star \star}$ & 2.825 & & 2.572 \\
\hline Empowerment & .539 & .595 & $8.917^{* * *}$ & .546 & .597 & $8.711^{* \star \star}$ & .246 & .269 & 1.027 \\
\hline Centralization & & & & -.058 & -.118 & -1.722 & -.450 & -.917 & -1.481 \\
\hline $\begin{array}{l}\text { Empowerment* } \\
\text { Central }\end{array}$ & & & & & & & .085 & .914 & 1.299 \\
\hline $\mathrm{R}^{2}$ & \multicolumn{3}{|l|}{.354} & \multicolumn{3}{|l|}{349} & \multicolumn{3}{|l|}{.356} \\
\hline Adj-R ${ }^{2}$ & \multicolumn{3}{|l|}{.350} & \multicolumn{3}{|l|}{.340} & \multicolumn{3}{|l|}{343} \\
\hline F value & \multicolumn{3}{|c|}{$79.505^{* * *}$} & \multicolumn{3}{|c|}{$38.018^{* * *}$} & \multicolumn{3}{|c|}{$26.030^{* * *}$} \\
\hline
\end{tabular}

Note: $\mathrm{P}$-value ${ }^{* * *}$ represents significant level at 0.001 or below, $\mathrm{P}$-value ${ }^{* *}$ represents significant level at 0.01 or below, $\mathrm{P}$-value* represents significant level at 0.05 or below.

\section{Discussion}

The role of the IS manager in postmodern organizations is to implement strategy, lead systems implementation projects, and act as a counterpart to the general manager (Pearlson and Saunders, 2006, p.220). However, whether the kind of IS managers can generate higher performance of IS department is an interesting, but not yet well-explored, issue in information systems. The fundamental objective of this study was to examine the relationship between empowerment of IS Managers and IS department performance. To answer this question, we investigated the affects of leadership, personality, and organizational culture and structure on the answer to our fundamental research question. Several conclusions can be drawn from our findings.

First, IS mangers when given high levels of empowerment, will have higher department performance. Higher Empowerment of IS manager helps to improve ISD performance. The results found in this analysis are consistent with or close to the results of previous studies -- employees who feel more empowered are more motivated to perform effectively (Chen et al., 2007; Chen \& Klimoski, 2003; Liden et al., 2000; Seibert et al., 2004). For example, Spreitzer $(1995,1997)$ found that psychological empowerment has a significant positive influence on managerial effectiveness, employee effectiveness, and innovation 
Key Characteristics of a Successful IS Manager: Empowerment, Leadership and personality / White et al.

in the workplace. Research on empowered teams also indicates positive outcomes. More empowered teams have better workunit performance (Seibert, et al., 2004), productivity (Kirkman \& Rosen, 1999), and team process improvement (Spreitzer, Noble, Mishra, \& Cooke, 1999).

The second conclusion is that transformational leadership of IS manager has a positive impact on IS department performance. This result supports Bass \& Avolio's theory (1990) that transformational leaders help their followers to reach their full potential and generate the highest level of individual and team performance. Other scholars have also found that transformational leadership is positively related to performance (Lowe, Kroeck \& Sivasubramaniam, 1996).

The third and the fourth conclusions concern the affect of personality on managerial performance. Conscientiousness and Agreeableness, as measured by the Big Five personality traits of IS managers have significant impact on IS department performance. The other three --Extroversion, Neuroticism, and Openness to Experience, appear to have no significant impact on IS department performance. This result is similar to that found in other research where in Conscientiousness has been suggested to be the primary dispositional predictor of job performance (Mount \& Barrick, 1995). Barrick \&Mount (1991) found that the relationship between emotional stability (less Neuroticism) and job performance was indistinguishable from zero, whereas Tett, Jackson, \& Rothstein (1991) found that emotional stability no correlation with job performance.

IS managers classified as Internal LOC have significantly higher IS departmental performance than IS managers classified as External LOC. This result agrees with Spector (1982) who concluded that people with Internal Locus of Control perform better than people with External Locus of Control. Weiss and Sherman's (1973) research showed that when individuals with internal LOC are faced with discrepancies between acceptable standards of performance and actual perfor- mance, they tend to increase their efforts to match their performance to the standards. This could account for the higher performance of departments managed by Internals.

As for the influence of organizational environment on IS department performance, we found no significant moderating effect of organizational culture or structure on the empowerment of IS manager and IS department performance

These findings are useful in that they provide insights into the issue of how IS managers affect the performance of IS department. We know that high empowerment of IS managers is a critical factor for high performing IS department. Transformational leadership and internal locus of control are also very important. IS managers can use the findings to help improve their management style. Additionally, CEO's can use these findings to select IS managers who are more suitable for such a position, adapt structures more suitable to current empowerment strategies, and direct Human Resource Departments to develop appropriate training programs that develop the transformational leadership characteristics of IS managers that will lead to increased organizational performance.

Our study is limited by the small number of participants as well as the focus on Taiwanese organizations. Future research investigating similar issues should be expanded to include diversity of culture and geography. The performance measures were mostly subjective in our study. Future research should also seek more hard data on IS department performance; such as, employee productivity and yield rate of products.

Further, this study focused on four transformational leadership attributes; future research could broaden the inventory of leader characteristics for a more inclusive picture of the attributes that influence the performance of subordinates.

We used only two factors of organizational structure in this study-formalization and centralization. Future research might want to include factors such as organizational size, 
Key Characteristics of a Successful IS Manager: Empowerment, Leadership and personality / White et al.

hierarchical level, and technology (Collins \& Hull, 1986; Perrow, 1967). Doing so would provide a more complete picture of the relationship between structure and performance.

Nonetheless, the results of this study would appear to be applicable to organizations units beyond what is found here for IS departments. The extant research on empowerment has focused on the effect of empowerment as a

\section{References}

Ajzen, I., Czasch, C., \& Flood, M. G. (2009). From intentions to behavior: Implementation intention, commitment, and conscientiousness. Jounal of Applied Social Psychology, 39, pp.1356-1372.

Ashforth, B. E. (1989). "The experience of powerlessness in organizations," Organizational Behavior and Human Decision Processes, 43, pp.207-242.

Bass, B.M. (1960). Leadership, Psychology, and Organizational Behavior. Oxford, England: Harper.

Bass, B. M. (1985). Leadership and Performance Beyond Expectations. New York: Free Press.

Bass, B. M. \& Avolio, B. J., (1990). Transformational leadership development: Manual for the Multifactor Leadership Questionnaire. Palo Alto, CA: Consulting Psychologists Press.

Barrick, M. R., Mount, M K., (1991). "The Big Five personality dimensions and job performance: A meta-analysis," Pres. Psychology, 44, pp.1-26.

Beer, S. (1979) The Heart of the Enterprise, John Wiley, Chichester, England.

Bell, N. E., Staw, B. M. (1989). People as sculptors versus sculpture. In M. B. Arthur, D. T. Hall, and B. S. Lawrence (eds.) Handbook of Carrer Theory. New York : Cambridge University Press.

Berger, Chris J., and Cummings Larry L., (1979). Organizational structure, atti- personal attribute while ours sheds an increment of light on empowered leadership at a functional-- IS department-- level and its impact on follower performance. It is our hope that these findings will facilitate research on total organization empowerment and its effect on competitive advantage and ultimately, organizational performance and profitability.

tudes and behavior. In Barry M. Staw (ed.), Research in Organizational Behavior. 1:169-208. Greenwich, CT: JAI Press.

Boudarias, J. S., Gaudreau, P. Laschinger, H. K. S. (2004). "Testing the structure of psychological empowerment: Does genders make a difference?" Educational and Psychological Measurement, 64(5), pp.861-877.

Borman, W. C. Rosse, R. L., Abrahams, N. M., (1980). "An empirical construct validity approach to studying predictorjob performance links," J. Appl. Psychol. 65, pp.662-671.

Bowen, D.E., Lawler, E.E. (1992). "The Empowerment of Service Workers: What, Why, How and When?" Solan Management Review, 33, pp.31-39.

Brockhaus, R. H. (1975). "I-E locus of control scores as predictors of entrepreneurial intentions," Academy of Management Proceedings , pp.433-435

Buss, D.M. (1991). Evolutionary personality psychology. In Rosenzweig MR, Porter LW (Eds.) Annual Review of Psychology. 42, pp.459-492. Palo Alto, CA:Annual Reviews Inc.

Buss AH. (1989). Personality as traits. American Psychology. 12:277-294.

Carter, L.F. (1953). Leadership and Small Group Behavior. Oxford, England: Harper.

Champion. D. J. (1975). The sociology of organizations. New York:McGraw-Hill. 
Key Characteristics of a Successful IS Manager: Empowerment, Leadership and personality / White et al.

Chen, G., Kirkman, B., Kanfer, R., Allen, D., Rosen, B. (2007). "A Multilevel Study of Leadership, Enpowerment, and Performance in Teams," Journal of Applied Psychology, 92(2), pp.331346.

Chen, G. and Klimoski, R.J. (2003), "The impact of expectations on newcomer performance in teams as mediated by work characteristics, social exchanges, and empowerment", Academy of Management Journal, Vol. 46 No. 5, pp.591-607.

Child. J. (1974). Comments on Reimann and Mansfield's "bureaucracy". Administrative Science Quarterly. 19:247-250.

Collins, P.D. \& Hull, F. (1986). "Technology and span of control: Woodward revisited", Journal of management studies. 23:143-164.

Collins James C. and Porras Jerry I.. (1994). Built to Last: Successful Habits of Vicionary Companies. New York: HarperBusiness.

Collins, James C. (1995). Change is good-but first know what should never change. Fortune. 29, p.141.

Colbert, A. E., \& Witt, L. A. (2009). The role of goal-focused leadership in enabling the expression of conscientiousness. Journal of Applied Psychology, 94. 790-796.

Conger, J. A., \& Kanungo, R. N. (1988). "The empowerment process : Integrating theory and practice," Academy of Management Review, 13, pp.471-482.

Costa, P. T. Jr. \& McCrae R.R., (1992). "An introduction of the Five-Factor model and its applications," Journal of Personality, 60(2), pp.175-215

Costa PT Jr, McCrae RR. Contemporary personality psychology: Implications for geriatric neuropsychiatry. In: Coffey CE, Cummings JL (eds.), Textbook of Geriatric Neuropsychiatry (2nd ed.).
Washington, DC: American Psychiatric Press, 1999.

Daft Richard L. (2007). The leadership experience. $4^{\text {th }}$ Edition. Thomson. SouthWestern. pp.420-451.

Day, D. A. Silverman, S. R. (1989). Personality and job performance: Evidence of incremental validity. Pres. Psychol. 42:25-36.

Dalton, D.R., Todor, W.D., Spendolini, M. J., Fielding, G.J., \& Porter, L.W. (1980). "Organization structure and performance: a critical review," The Academy of Management Review, 5 (1), pp.49-64.

Deal T.E. and Kennedy A. A., (1999). The new corporate cultures: revitalizing the workforce after Downsizing, mergers, and reengineering. Perseus Books.

Denison Daniel R. and Mishra Aneil K. (1995). "Toward a theory of organizational culture and effectiveness," Organization Science, 6(2):204-223.

Digman J. M., (1990). "Personality Structure: Emergence of the five-factor model ", Annual Review of Psychology. 41, pp.417-440

Durand, D., Shea, D. (1974). "Entrepreneurial Activity as a Function of Achievement Motivation and Reinforcement Control", The Journal of Psychology, 88, pp.57-63.

Driskell, J. E., Hogan, R., Salas. E., (1987). "Personality and group performance," Rev. Personal. Social Psychology, 9, pp.91-113.

Eagly A.H. and Johannesen-Schmidt, M.C. (2001), "The Leadership styles of Woman and Men," Journal of Social Issues, 57(4), pp.781-797.

George, J. M., (1992). "The role of personality in organizational life: Issues and evidence," J. Manage, 18(2), pp.185213. 
Key Characteristics of a Successful IS Manager: Empowerment, Leadership and personality / White et al.

Gist, M. (1987). "Self-efficacy: Implications for organizational behavior and human resource management," Academy of Management Review, 12(3):472-485.

Goldberg LR. (1992). "The development of markers for the Big Five factor structure," Psychological Assessment, 4, pp.26-42.

Goldberg LR. (1993). "The structure of phenotypic personality traits," American Psychologist, 48, pp.26-34.

James, Lawrence R., and Allan P. Jones. (1976). "Organizational structure: A review of structural dimensions and their conceptual relationships with individual attitudes and behavior," Organizational behavior and Human Performance, 16, pp.74-113.

Goodstadt, Barry E.\& Hjelle, Larry A. (1973). "Power to the powerless: Locus of control and the use of power," Journal of Personality and Social Psychology, pp.190-196.

House, R. J., Woycke, J. \& Fodor, E. M. (1988). Charismatic and noncharismatic leaders: Differences in behavior and effectiveness. In J. A. Conger \& R. N. Kanungo (Eds), Charismatic leadership: The Elusive Factor in Organizational effectiveness. San Francisco, CA: Jossey-Bass.

Johnson, A., Luthans, F., \& Hennessey, $H$. (1984). "The role of locus of contral in leader influence behavior," Personnel Psychology, 37(1), pp.61-75

John, O. P., \& Srivastava, S. (1999). The Big Five trait taxonomy : History, measurement, and theoretical perspectives. In L. R. Pervin, \& O. P. John(Eds.), Handbook of personality: Theory and research (pp.102-138). New York: Guilford Press.

Kahn Jeremy, (1998). "What makes a company Great? “ in Fortune, 26, p.218.

Keen, P.G.W. (1980). "MIS Research: Reference Disciplines and a Cumulative
Tradition", in Proceedings of the First International Conference on Information Systems, McLean, E.R. (Ed.), Philadelphia, Pennsylvania, December 1980, pp.9-18.

Kirman, B.L. \& Rosen, B. (1999). "Beyond Self -Management: The Antecedents and Consequences of Team Empowerment," Academy of Management Journal, 42, pp.58-71.

Kirkman, B.L., Tesluk, P.E., and Rosen, B. (2004). "The Impact of Demographic Heterogeneity and Team LeaderTeam Member Demographic fit on Team Empowerment and Effectiveness," Group \& Organization Management, 29 (3), pp.334-368.

Koberg, C.S., Boss, J.C., Senjem, J.C., Goodman, E.A. (1999). "Antecedents and Outcomes of Empowerment Empirical Evidence from the Health Care Industry," Group \& Organization Management, 24(1), pp.71-91.

Kohn, Melvin L., and Schooler Carmi. (1973). " Occupational experience and psychological functioning: An assessment of reciprocal effects," American Sociological Review, 38, pp.97118.

Laudon, K. C.,\& Laudon, J. P. (2002). Management information systems: Managing the detail firm ( $7^{\text {th }}$ ed.). $\mathrm{NJ}$ :Prentice Hall.

Leavitt, Harold J. (1964). Applied organization change in industry: Structural, technical, and Human Approaches. In New Perspectives in organization research. W. W. Cooper, H. J. Leavitt, and M. W. Shelly, eds. New York: John Wiley \& Sons, Inc.

Liden, R., Robert, C., Wayne, S.J., Sparrowe, R.T. (2000). "An Examination Of The Mediating Role of Psychological Empowerment on The Relations Between The Job, Interpersonal Relationship, and Work Outcome," Journal of Applied Psycjology, 85(3), pp.407-416. 
Key Characteristics of a Successful IS Manager: Empowerment, Leadership and personality / White et al.

Liden, R. C., \& Arad, (1996). A power perspective of empowerment and work groups: Implication for HRM research. In G. R. Ferris (Ed.), Research in personnel and HRM, vol. 14:205-252. Greenwich, CT:JAI Press.

Lowe, K. B., Kroeck, K. G., Sivasubramaniam, N. (1996). Effectiveness correlates of transformational and transactional leadership: A meta-analytic review of the $M L Q$ literature. Leadership Quarterly, 7:385-425.

Mathiew, J.E., Gilson, L.L., and Ruddy, T.M. (2006). "Empowerment and Team Effectiveness: An Empirical Test of an Integrated Model," Journal of Applied Psychology, 91 (1), pp.97-108.

McCrae RR and Costa PT. (1987). "Validation of the five-factor model of personality across instruments and observers," Journal of Personality and Social Psychology, 52, pp.81-90.

McCrae RR and Costa PT. (1989). "More reasons to adopt the five-factor model," American Psychologist, 44, pp.451-452.

McDonald, P. \& Gandz, J. (1992). "Getting Value form Shared Values," Organizational Dynamics, 20(3), pp.64- 77.

Mitchell, T. R., Smyser, C. M. \& Weed, S. E. (1975). "Locus of control : supervision and work satisfaction", Academy of Management Journal, 18(3),pp.623631

Mitroff, I. I. (1983). Stakeholders of the organizational mind. San Francisco: Jossey-Bass.

Mitroff, I. I. and Kilmann, R. H. (1975). "Stories managers tell: A new tool for organizational problem solving," Management Review, pp.18-28.

Mitroff, I. I. and Kilmann, R. H. (1976). On organizational stories : An approach to the design and analysis of organization through myths and stories. In $\mathrm{R}$. Kilmann, L. R. Pondy, and D. Slevin
(Eds.), The management of organization design, New York: Elsevier North Holland.

Montanari, J. R. (1978). Operationalizing strategic choice. In J. H. Jackson \& C. P. Morgan. 1978. Organization theory: A macro perspective for management. Englewood Cliffs, N. J.: Prentice-Hall, Inc. pp.286-298.

Morris, T. and Seeman, M. (1950). "The Problem of LeadershipL An Interdisciplinary Approach," The American Journal of Sociology, 56 (2), pp.149155.

Thomas, K. W., \& Velthouse, B. A. (1990). "Cognitive elements of empowerment, : An interpretive model of intrinsic task motivation". Academy of Management Review, 15, pp.666-681.

Trevino, L.K. (1999). "Business Ethics and the Social Sciences", in A Companion to Business Ethics, Frederick, R.E. (Ed.), Blackwell Publishers, Oxford, England, pp.218-230.

O'Toole, J.\& Lawler, E.E. (2006). The new American workplace. New York : Palgrave-Macmillan.

Pearlson Keri E. and Saunders Carol S., (2006). Managing and Using information Systems-A Strategic Approach, Wiley.

Perrow C., (1967). "A framework for the comparative analysis of organizations," American sociological review, 32, pp.194-208

Porter, L.W., \& Lawler, E.E. (1965). "Properties of organization structure in relation to job attitudes and job behavior," Psychological Bulletin, 64, pp.23-51.

Pugh, D. S., D. J. Hickson, C. R. Hinings, and C. Yurner. (1968). "Dimensions of organization structure," Administrative Science Quarterly, 13, pp.65-105.

Prasad, A. (2001). "Understanding workplace empowerments as inclusion: A historical investigation of the discourse of 
Key Characteristics of a Successful IS Manager: Empowerment, Leadership and personality / White et al.

difference in the United States," Journal of Applied Behavioral Science, 37(1):51-59.

Prasad, A. \& Eylon, D. (2001). "Narrative past traditions of participation and inclusion: Historic perspectives on workplace empowerment," Journal of Applied Behavioral Science, 37(1), pp.5-14.

Schein, E. H. (1990). Organizational Culture. American Psychologist. 45(2), pp.109119.

Schein, E. H. (1992). Organizational culture and leadership. San Francisco: Jossey-Bass.

Seibert, S. E, Silver, S. R., \& Randolph, W. A. (2004). Taking empowerment to the next level: A multiple-level model of empowerment, performance, and satisfaction, Academy of Management Journal, 43, 3, 332- 349.

Spector, P. E. (1982). Behavior in organizations as a function of employee's locus of control. Psychological Bulletin. 91:482-497.

Speritzer, P.E., Dwyer, D.J., Jex, S.M. (1988). "Relation of Job Stressors to Affective, Health, and performance Outcomes: A Comparison of Multiple Data Sources," Journal of Applied Psychology, 73 (1), pp.11-19.

Spreitzer, G. M. (1995). "Individual empowerment in the workplace: Dimensions, Measurement, validation," Academy of Management Journal, 38(5), pp.1442-1465.

Spreitzer, Gretchen M., Kizilos, Mark, and Nason, Stephen. (1997). "A dimensional analysis of the relationship between psychological empowerment and effectiveness, satisfaction, and strain," Journal of Management, 23(5), pp.679-704.

Spreitzer, G. M., Janasz, S.C., and Quinn, R. T, (1999). "Empowered to lead: the role of psychological empowerment in leadership," Journal of Organizational Behavior, 20, 511-526.

Speritzer, G.M., Noble, D.S., Mishra, A.K., and Cooke, W.N. (1999). Predicting Process Improvement Team Performance in an Automotive Firm: Explicating the Role of Trust and Empowerment, in E. Mannix \& M. Neale (eds.), Research on Managing Groups and Teams, 2, Greenwich, CT:JAI Press, pp.71-92.

Tett. R. P., Jackson, D. N., Rothstein, M., (1991). "Personality measures as predictors of job performance: A metaanalytic review," Pres. Psychol. 44, pp.703-741.

Wat, D., Shaffer, M.A. (2005). "Equity and Relationship Quality Influences on Organizational Citizenship Behaviors," Personnel Review, 34 (4), pp.406-422.

Weiss, H., \& Sherman, J. (1973). "Internalexternal control as a predictor of task effort and satisfaction subsequent to failure," Journal of Applied Psychology. 57:132-136.

Wiggins J. S. and Pincus A. L., (1992) "Personality: Structure and Assessment" Annual Review of Psychology, 43, pp.473-504.

Zimmer Carl, (2005). Looking for personality in Animals of all people. The New York Times. P. F1 
Key Characteristics of a Successful IS Manager: Empowerment, Leadership and personality / White et al.

\begin{abstract}
About the Authors
Louis $\mathbf{P}$. White received a Ph.D. in Industrial organizational Psychology from the University of South Florida. He has extensive experience in international education with particular expertise in Taiwan. His consulting experience has been in health care, aerospace, petrochemical, city government, steel, and construction organizations in Taiwan and the U.S. Dr. White's research has appeared in The Academy of Management Review, The Human Resource Quarterly, Human relations, The Training and Development Journal, Journal of Business Ethics and other scholarly Journals. His book "Professional Ethics and practice in organizational Development: A systematic Analysis of Issues, Alternatives, and Approaches is recognized for its contribution to the field of Organizational Development.
\end{abstract}

Constance M. Lafayette graduated in 2009 from the University of Houston-Clear Lake,
Summa Cum Laude. She is a Human Resource Management professional with more than fifteen years of domestic and international experience in strategic planning, developing, and managing. She is currently working as a Human Resource Specialist for Total Safety, U. S. Inc., the leading global provider of integrated safety solutions.

Rachel Yu-Ning Wang received her B.A. in Nutritional \& Food Sciences from the Providence University, Taiwan in 1994 and her M.B.A. from the National Sun Yat-Sen University, Taiwan in 2009. She is now serving as Chief of Administrative Staff at the Institute of Molecular Medicine, College of Medicine at the National Cheng Kung University providing her professional assistance and leadership in business and budgetary management as well as in health research and education. 